\title{
Proposals for nutritional assessments of feeds from genetically modified plants
}

\author{
G. Flachowsky ${ }^{1}$ and H. Böhme \\ Federal Agricultural Research Centre, Institute of Animal Nutrition \\ Bundesallee 50, 38116 Braunschweig, Germany
}

\begin{abstract}
The cultivation of genetically modified plants (GMP) increased from 1.7 to 81 million. ha from 1996 to 2004 (James, 2004). Scientists and farmers, but also consumers, are asking for a nutritional assessment, including safety aspects, of feeds from those plants. Substantial equivalence was created as a framework for the compositional assessment of feeds from GMP of the so-called first generation (without substantial changes of composition or without output traits) and is widely accepted. However, comprehensive studies are necessary for feeds from GMP of the second generation, with substantial changes in composition and nutritional value or so-called output-traits.

The paper summarizes proposals for the nutritional assessment of feeds from GMP of the first generation and discusses experimental designs for assessing feeds from GMP of the second generation.
\end{abstract}

KEY WORDS: genetically modified plants, input traits, output traits, nutritional value

\section{INTRODUCTION}

In 2004, genetically modified plants (GMP) were cultivated on an estimated area of 81 million hectares worldwide (James, 2004), with growth rates of between 15 and $20 \%$ per year. Soyabean, maize, cotton and oilseed rape are the most important GM crops. Based on the production whole plants, plant parts (seeds, straw, etc.), silages or processing by-products (extracted oilmeals, maize distillers, etc.) are available for animal nutrition. On all occasions, technological advances involve risks, and plant transgenesis is no exception in this rule. Most consumers perceive a potential GMP-related risk to their own or animal health and to the environment.

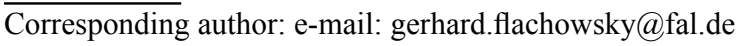


Therefore adequate studies are necessary to assess the potential risks of GMP for humans, animals and the environment. The nutritional assessment of feeds from GMP is an essential part of such studies. The combination of experiments for the nutritional assessment of feeds from GMP with risk assessment studies should be a further objective of such measurements (Kuiper and Kleter, 2003; Cellini et al., 2004; EFSA, 2004).

Many studies exist in which feeds from GMP were compared with isogenic hybrids. In most experiments, feeds from GMP with agronomic traits such as increased resistance or tolerance against herbicides or insects and low changes in chemical composition (GMP of the first generation) were tested. Results of such studies were recently summarized by Clark and Ipharraguerre (2001), Flachowsky and Aulrich (2001a), Aumaitre et al. (2002), Faust (2002), Chesson and Flachowsky (2003) and Flachowsky et al. (2005).

Nevertheless, there are still some questions open, especially on assessing the nutritive value of feed from GMP with substantial changes in their chemical composition (GMP of the second generation) such as:

- digestibility and/or bioavailability of nutrients

- comparison with control group/s

- number of animals and duration of experiments

- influence on animal health, welfare and fertility

- quality of foods of animal origin

- occurrence of unintended or unexpected effects.

The objective of this paper is to summarize the present state of recommendations for nutritional assessment of feeds from GMP worked out by organizations and scientific bodies as well as to make some proposals for experimental procedures to assess feeds from GMP with output traits (GMP of the second generation).

\section{GMP OF THE FIRST AND SECOND GENERATION}

Nutritionists distinguish GMP mostly between those from the first and second generation. This designation is purely pragmatic or historical; it does not reflect any particular scientific principle or technological development.

The first generation of GMP is generally considered to be crops carrying simple input traits such as increased resistance to pests or tolerance against herbicides. The proteins produced which confer these effects occur in very low concentrations in modified plants and do not significantly change their composition or the feeding value when compared to the isogenic lines. In contrast, the second generation of GMP includes plants in which nutrient composition or availability has been considerably changed by genetic engineering (Welch and Graham, 2004; Table 1). 
Table 1. Selected crops genetically modified with nutritionally improved traits indented to provide benefits to domestic animals and consumers (ILSI, 2004b)

\begin{tabular}{|c|c|c|}
\hline $\begin{array}{l}\text { Crop } \\
\text { Species }\end{array}$ & Trait & Transgene \\
\hline Lucerne & $\begin{array}{l}\text { +Phytase } \\
\text { +Resveratrol } \\
\text { Lignin } \downarrow\end{array}$ & $\begin{array}{l}\text { Phytase (Aspergillus) } \\
\text { Resveratrol glucoside } \\
\text { Down regulation of caffeic acid 3-O-methyltransferase } \\
\text { and caffeoyl CoA 3-O-metyhltransferase }\end{array}$ \\
\hline Canola & $\begin{array}{l}\text { VitaminE } \uparrow \\
\text { Lauric acid } \uparrow \\
\gamma \text {-Linolenic acid } \uparrow \\
+\omega-3 \text { Fatty acid } \\
+\beta \text {-Carotene } \\
\text { 8:0 and 10:0 fatty acids } \\
\text { Medium chain fatty acids } \uparrow\end{array}$ & $\begin{array}{l}\gamma \text {-Tocopherol methyltransferase (Arabidopsis) } \\
\text { Lauroyl ACP thioesterase (California bay tree) } \\
\delta-6-\text { and } \delta-12 \text { desaturases } \\
\delta-6 \text { Desaturase gene (Mortierella) } \\
\text { Phytoene synthase (daffodil) } \\
\text { Phytoene desaturase (Erwinia) } \\
\text { Lycopene cyclase (daffodil) } \\
\text { Ch FatB2, a thioesterase cDNA (Cuphea hookeriana) }\end{array}$ \\
\hline Cassava & Cyangenic glycosides $\downarrow$ & Hydroxynitril lyase \\
\hline Cotton & $\begin{array}{l}\text { Oleic acid } \uparrow \\
\text { High-oleic and high-stearic } \\
\text { cottonseed oils }\end{array}$ & $\begin{array}{l}\text { Mutant } \delta \text { - } 12 \text { desaturase } \\
\text { hpRNA-mediated post-transcriptional gene } \\
\text { silencing desaturases }\end{array}$ \\
\hline Lupin & Methionine $\uparrow$ & Seed albumin (sunflower) \\
\hline Maize & $\begin{array}{l}\text { Sulphur amino acids } \uparrow \\
\text { Fumonisin } \uparrow \\
\text { Insect resistance } \\
\text { Protein with favourable } \\
\text { amino } \\
\text { acid profile } \uparrow \\
\text { Vitamin } C \uparrow\end{array}$ & $\begin{array}{l}\text { mRNA stability by intron switching Dzr1 target } \\
\text { de-esterase-de-aminase (mbial) } \\
\text { Avidin (chicken) } \\
\alpha \text {-Lactabumin (porcine) } \\
\text { Maize } 15 \mathrm{kDa}-z e i n \\
\text { Wheat dehydroascorbate reductase (DHAR) }\end{array}$ \\
\hline Potato & $\begin{array}{l}\text { Starch } \uparrow \\
\text { Very-high-amylose starch } \uparrow \\
\text { Inulin molecules } \uparrow\end{array}$ & $\begin{array}{l}\text { ADP glucose pyrophosphorylase (Escherichia coli) } \\
\text { Inhibition of SBE A and B } \\
\text { 1-SST (sucrose:sucrose 1-fructosyltransferase) } \\
\text { and the 1-FFT (fructan:fructan 1-fructosyltrans-ferase) } \\
\text { genes of globe artichoke (Cynara scolymus) } \\
\text { Nonallergenic seed albumin gene (Amaranthus } \\
\text { hypochondriacus) }\end{array}$ \\
\hline & Solanine $\downarrow$ & Antisense sterol glyco transferase (Sgt) gene \\
\hline Rice & $\begin{array}{l}\text { Iron } \uparrow \\
\text { Allergenic protein } \downarrow\end{array}$ & $\begin{array}{l}\text { Phytoene synthase (daffodil) } \\
\text { Phytoene desaturase (Erwinia) } \\
\text { Lycopene cyclase (daffodil) } \\
\text { Ferritin (Phaseolus) } \\
\text { Metallothionein (rice) } \\
\text { Phytase (mutant, Aspergillus) } \\
\text { Antisense 16kDa allergen (rice) }\end{array}$ \\
\hline
\end{tabular}


Correspondingly, effects on the nutritional value of the feed are considered in detail. The following changes should be mentioned:

- GMP of the first generation (input traits)

- increased resistance (tolerance against herbicides or insecticides)

- increased tolerance against insects

- more efficient use of water and/or nutrients (e.g., P)

- increased resistance against heat and drought

- GMP of the second generation (output traits)

- increased content of desirable substances (e.g., amino acids, vitamins, fatty acids, minerals, enzymes)

- decreased content of undesirable substances (e.g., mycotoxins, alkaloids, glucosinolates, lignin, phytate)

GM with input traits (77\%) dominated the field trial notifications during the last decade in Europe, while output traits were relevant for only $18 \%$ of all notifications, with a decreasing trend during the last six years (Lheureux and Menrad, 2004).

From the nutritional point of view, various methods/steps for nutritional assessment of feeds from GMP of the first and second generation should be carried out as summarized in Figure 1. Additional details for recommended measures are given in one of our previous papers (Table 2).

\begin{tabular}{|c|c|c|}
\hline \multicolumn{3}{|c|}{ Feeds from GMP } \\
\hline $\begin{array}{l}\text { Characterization } \\
\text { of GMP }\end{array}$ & $\begin{array}{l}\text { GMP of first generation } \\
\text { Plants with input traits } \\
\text { Feeds without substantial changes } \\
\text { in composition (substantial } \\
\text { equivalent) }\end{array}$ & $\begin{array}{l}\text { GMP of second generation } \\
\text { Plants with output traits } \\
\text { Feeds with substantial changes in } \\
\text { composition }\end{array}$ \\
\hline \multirow[t]{3}{*}{$\begin{array}{l}\text { Steps for nutritional } \\
\text { assessment }\end{array}$} & $\begin{array}{l}\text { Determination of major and } \\
\text { minor nutrients and undesirable } \\
\text { substances }\end{array}$ & $\begin{array}{l}\text { Determination of major and } \\
\text { minor nutrients and undesirable } \\
\text { substances }\end{array}$ \\
\hline & $\begin{array}{l}\text { Case-by-case studies to compare } \\
\text { GM-feeds with isogenic } \\
\text { counterparts in target animal } \\
\text { species/categories }\end{array}$ & $\begin{array}{l}\text { Determination of bioavailability/ } \\
\text { bio-potency of changed nutrient/s } \\
\text { in target animal species/categories }\end{array}$ \\
\hline & & $\begin{array}{l}\text { Case-by-case (long term) feeding } \\
\text { studies to compare GM-feed with } \\
\text { variously supplemented isogenic } \\
\text { counterparts in target animal } \\
\text { species/categories }\end{array}$ \\
\hline
\end{tabular}

Figure 1. Steps for nutritional assessment of feeds from GMP 
Table 2. Proposal for the nutritional assessment of GMPs (from Flachowsky and Aulrich, 2001a)

\begin{tabular}{|c|c|c|}
\hline Parameter & $\begin{array}{l}\text { First } \\
\text { generation of } \\
\text { GMP }\end{array}$ & $\begin{array}{c}\text { Second } \\
\text { generation of } \\
\text { GMP }\end{array}$ \\
\hline \multicolumn{3}{|l|}{ Determinations of important constituents } \\
\hline - crude nutrients & + & ++ \\
\hline $\begin{array}{l}\text { - genetically modified nutrients (e.g., amino acids, fatty acids, } \\
\text { vitamins, enzymes etc.) }\end{array}$ & - & $++^{2}$ \\
\hline $\begin{array}{l}\text { - genetically modified undesirable substances (e.g., plant } \\
\text { constituents such as lignin, inhibitors, glucosides, etc., or } \\
\text { secondary substances, such as mycotoxins, pesticides, etc.) }\end{array}$ & $(+)$ & $++^{2}$ \\
\hline $\begin{array}{l}\text { Digestibility, conversion studies, availability of modified } \\
\text { nutrients in the target animal species }\end{array}$ & $(+)$ & ++ \\
\hline In vitro studies of nutritional assessment & $(+)$ & $(+)$ \\
\hline \multicolumn{3}{|l|}{ Feeding experiments with species/categories of target animal } \\
\hline $\begin{array}{l}\text { - performance of animals and quality of foods of animal } \\
\text { origin }\end{array}$ & $(+)$ & ++ \\
\hline - animal health & $(+)$ & $(+)$ \\
\hline - route taken by modified protein and/or DNA ${ }^{1}$ & + & + \\
\hline $\begin{array}{ll}\text { - not necessary } & + \text { recommended } \\
(+) \text { may be advantageous } & ++ \text { necessary }\end{array}$ & $\begin{array}{l}{ }^{1} \text { for scientific } \mathrm{p} \\
{ }^{2} \text { for modified } \mathrm{c}\end{array}$ & $\begin{array}{l}\text { urposes } \\
\text { omponents }\end{array}$ \\
\hline
\end{tabular}

\section{PROPOSALS FOR NUTRITIONAL ASSESSMENT OF GMP OF THE FIRST GENERATION}

Various concepts exist for the nutritional assessment of GMP of the first generation. Most concepts are based on proposals of scientific or administrative bodies like CAST, EFSA, ILSI or OECD.

Substantial equivalence (SE; OECD, 1993)

The concept of SE is based on the idea that an existing plant used as feed with a history of safe use and known feeding value can serve as a comparator when assessing the safety and the feed value of a genetically modified plant (OECD, 1993; EC, 1997). SE is the starting point for the nutritional and safety assessment of GM-material and can be described as a comparative approach for the assessment of safety (EFSA, 2004). The OECD (2001c) regards SE as a suitably robust framework for the nutritional and safety assessment of the first generation of GM plants. Compositional analysis is a cornerstone for the nutritional assessment of new crop varieties, whether they are bred conventionally or derived from modern biotechnology. It should be noted that there are significant differences in the composition of conventionally bred varieties within crops, and 
therefore the compositional analysis of GM-crops must be assessed in connection with the natural variability in their conventional counterpart(s). Although the term substantial equivalence was introduced for the assessment of foods, it is equally relevant to the safety assessment of those plants and their products used as feedstuffs.

According to the OECD (1993), a "new" food or a new food ingredient is regarded as substantially equivalent if no significant differences occur in comparison with an appropriate traditional source. A food/feed plant is substantially equivalent if it corresponds to a conventional variety in its agronomy, composition, metabolic processes and its content of undesirable substances. If SE can be established by analogy, the novel food can be assumed to be as safe as the material to which it was compared. The provisions of the former "Novel Food" Regulation (Regulation No. 258/97 of 15.05.1997; EC 1997) were based on these definitions. In practise, $\mathrm{SE}$ is assessed mainly by comparing the agronomic characteristics of the plant and its composition. However, in determining the degree of equivalence, it should not be overlooked that conventional feedstuffs also have a considerable biological variability in their growth characteristics and constituents. The consensus documents on the compositional considerations of new varieties of soyabean, maize, potatoes, rapeseed and sugar beet prepared by OECD (2001a,b; 2002a,b,c; 2003a) and ILSI (2003a) database excellent guidance for the analyses needed as part of the nutritional assessment of GM-crops modified for agronomic traits.

\section{Best practices for animal studies to assess GMP OF the first generation (ILSI, 2003b)}

Scientists in many areas of the world have expressed a desire to conduct animal studies to evaluate feeds from GM-crops. Because of the potential effect of the results from these studies on the future of genetic modification of plants, it is imperative that studies be conducted with the utmost scientific rigor and sensitivity. Therefore the International Life Science Institute (ILSI) asked scientists all over the world with expertise in areas such as animal nutrition and welfare, feed chemistry and other relevant disciplines to contribute to the development of guidelines for the best practices for conducting animal studies to evaluate crops genetically modified in their input traits (ILSI, 2003a,b). The purpose of the document is to recommend guidelines to scientists on how to produce, handle, store, and process transgenic crops containing input traits; how to sample and analyse the harvested and processed crop; how to design and conduct animal studies, and how to analyse and interpret the results. ILSI (2003b) focuses on input traits (i.e. traits such as those that protect the crop against disease or insect damage or that provide tolerance to herbicides; GMP of the so-called first generation). 
Some recommendations from the "Best practices for the conduct of animal studies to assess the nutritional value of feeds from GMP of the first generation" are given in Table 3 .

Table 3. Some recommendations from the "Best practices for the conduct of animal studies to evaluate crops genetically modified for input traits (GMP of the first generation)"; adapted from ILSI (2003b)

\begin{tabular}{|c|c|c|c|c|}
\hline $\begin{array}{l}\text { Animals (species/ } \\
\text { categories) }\end{array}$ & $\begin{array}{l}\text { Number of animals } \\
\text { (coefficient of } \\
\text { variation } 4 \text { to } 5 \% \text { ) }\end{array}$ & $\begin{array}{l}\text { Duration of } \\
\text { experiments }\end{array}$ & $\begin{array}{l}\text { Composition } \\
\text { of diets }{ }^{1}\end{array}$ & Measurements \\
\hline $\begin{array}{l}\text { Poultry for meat } \\
\text { production }\end{array}$ & $\begin{array}{l}10 \text { to } 12 \text { pens per } \\
\text { treatment with } 9 \text { to } \\
12 \text { birds per pen }\end{array}$ & 5 weeks or more & $\begin{array}{l}\text { Balanced } \\
\text { diets }\end{array}$ & $\begin{array}{l}\text { Feed intake, gain, } \\
\text { feed conversion }\end{array}$ \\
\hline $\begin{array}{l}\text { Poultry for egg } \\
\text { production }\end{array}$ & $\begin{array}{l}12 \text { to } 15 \\
\text { replications per } \\
\text { treatment with } 3 \text { to } \\
5 \text { layers per pen }\end{array}$ & $\begin{array}{l}18 \text { to } 40 \text { weeks of } \\
\text { age, at least three } \\
28 \text {-day phases }\end{array}$ & $\begin{array}{l}\text { Balanced } \\
\text { diets }\end{array}$ & $\begin{array}{l}\text { Feed intake, egg } \\
\text { production, feed } \\
\text { conversion, egg } \\
\text { quality }\end{array}$ \\
\hline Pigs & $\begin{array}{l}6 \text { to } 9 \text { replications } \\
\text { per treatment with } \\
4 \text { or more pigs per } \\
\text { replication }\end{array}$ & $\begin{array}{l}\text { Piglets }(7-12 \mathrm{~kg}) \text {, } \\
\text { 4-6 weeks } \\
\text { Growers }(15-25 \\
\mathrm{kg}), 6-8 \text { weeks }\end{array}$ & $\begin{array}{l}\text { Balanced } \\
\text { diets }\end{array}$ & $\begin{array}{l}\text { Feed intake, gain, } \\
\text { feed conversion, } \\
\text { carcass quality }\end{array}$ \\
\hline $\begin{array}{l}\text { Growing and } \\
\text { finishing ruminants }\end{array}$ & $\begin{array}{l}6 \text { to } 10 \text { replications } \\
\text { per treatment with } \\
6 \text { or more cattle per } \\
\text { replication }\end{array}$ & $90-120$ days & $\begin{array}{l}\text { Balanced } \\
\text { diets }\end{array}$ & $\begin{array}{l}\text { Feed intake, gain, } \\
\text { feed conversion, } \\
\text { carcass data }\end{array}$ \\
\hline Lactating dairy cows & $\begin{array}{l}12-16 \text { cows } \\
\text { per treatment } \\
28 \text { cows per } \\
\text { treatment }\end{array}$ & $\begin{array}{l}\text { Latin square: } 28 \\
\text { day periods } \\
\text { Randomized block } \\
\text { design }\end{array}$ & $\begin{array}{l}\text { Balanced } \\
\text { diets }\end{array}$ & $\begin{array}{l}\text { Feed intake, milk } \\
\text { performance and } \\
\text { composition, } \\
\text { body weight, } \\
\text { body condition } \\
\text { score (BCS), cell } \\
\text { counts in milk, } \\
\text { animal health }\end{array}$ \\
\hline
\end{tabular}

${ }^{1}$ feed from GMP should be included in high portions in diets and compared with isogenic counterparts

In a further publication, ILSI discussed animal experimentation with feeds from GMP with output traits (i.e. traits that increase nutritional value, reduce naturally occurring toxicants, enhance flavour, or yield pharmaceutical products; GMP of the second generation, ILSI, 2004). 
OECD-document (OECD, 2003b) for the safety assessment

OECD (2003b) considers establishing the degree of equivalence to conventional varieties as a useful starting point for the safety and nutritional assessment. Feeding trials with GMP with modified input traits (e.g., herbicide tolerance) to confirm safety and/or nutritional value are considered as generally unnecessary. To date, such plants have been shown to be compositionally equivalent to their conventional counterpart.

\section{EFSA-GUIDANCE document (EFSA, 2004) - GMP of the first generation}

Once compositional equivalence has been established in GM-feeds modified for agronomic input traits, nutritional equivalence can be assumed (Clark and Ipharraguerre, 2001; Flachowsky and Aulrich, 2001b), since routine long-term livestock feeding studies generally add little to nutritional assessment. In the case of crops modified for agronomic input traits with combined events, the need for long-term feeding studies should be assessed on a case-by-case basis.

\section{Decision tree for various questions}

Given the almost complete lack of public acceptance of "green genetic engineering" today it is essential that the approach taken to any safety assessment be clearly laid out and be transparent to all stakeholders. The proposal of a "decision tree" shown in Figure 2 offers a clear and stepwise series of actions. Depending on the results of each step, further studies follow in order to identify any unforeseeable effects. The questions on the left and right sides given in Figure 2 are a reflection of the present situation and the need for a large measure of standardization of studies on the nutritional assessment of GM-plants. In the case of crops modified for agronomic input traits with stacked genes, the need for longer-term feeding studies should be assessed on a case-by-case basis. Then the decision tree is also suitable to give answers for the nutritional and safety assessment of GMP of the second generation as discussed later. 


\section{Further questions}

- What should be done if no isogenic counterparts exist?
- Are side-effects nevertheless to be expected?

- Can in vitro studies possibly answer further questions?

- Are side-effects nevertheless to be expected?
- Are side-effects nevertheless to be expected?
PRINCIPAL QUESTIONS

Are there significant differences in relevant constituents between feedstuffs from isogenic and transgenic plants?

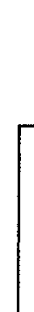

\section{Yes}

No further studies if the principle of substantial equivalence is accepted
End of evaluation

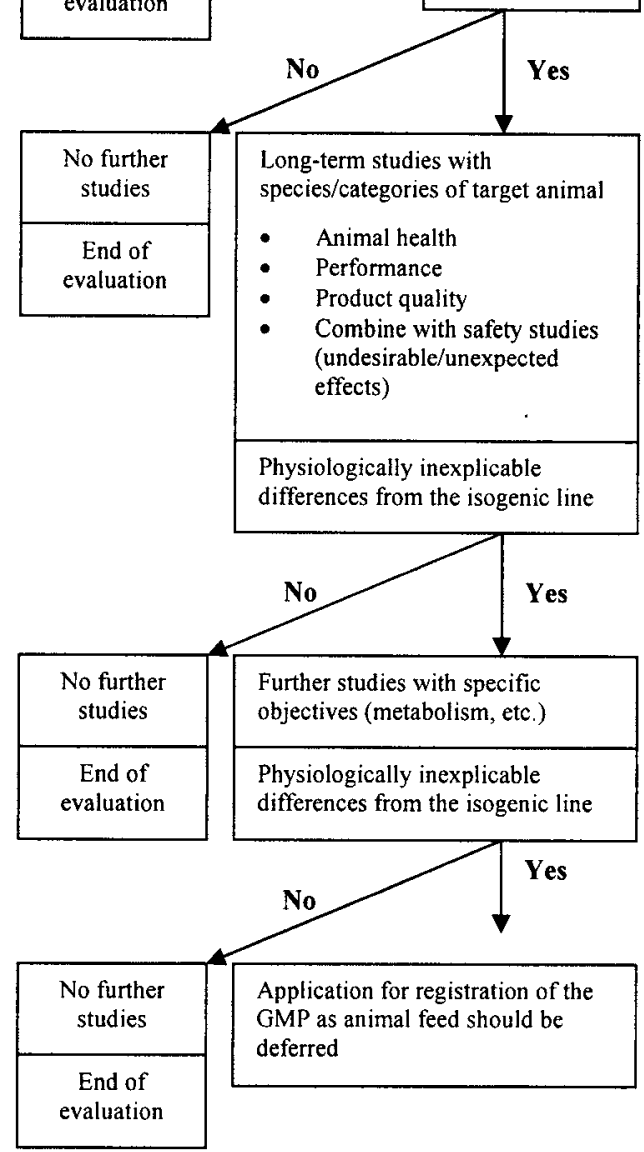

\section{Further questions}

- Which constituents should be studied?

- What will be used for comparison (isogenic line or natural population)?

- Formulation of rations?

- Comparison (isogenic line or natural population)?

- What comparison if there is no isogenic counterpart?
- Experimental protocol?

- Formulation of rations

- Animal species/number

- What comparison

- Routes taken by DNA or transgenic protein?

- Importance of in vitro studies or other less costly studies with representative conclusions?

- What type of further studies?

- Consideration of $F_{1}+\left(F_{2}\right)$ generation

- Changes in intestinal flora?

- Extend studies to multidisciplinary studies?

- Histology

- Pathology

- Toxicology, etc.

Figure 2. Proposal for a decision tree for the nutritional assessment of feedstuffs from GMPs (Flachowsky and Aulrich, 2001b) 


\section{PROPOSALS FOR NUTRITIONAL ASSESSMENT OF GMP OF THE SECOND GENERATION}

Compositional analyses to determine the modified nutrient/s or the reduced undesirable substance/s and in vitro studies to characterize the changed substance/ $\mathrm{s}$ apart from animals are essential prerequisites for a nutritional assessment of GMP and for animal studies. In the case of GM crop plants with improved nutritional characteristics (second generation plants, output traits), various types of livestock feeding studies with target species should be conducted on a case-by-case basis to confirm the expected nutritional benefits (e.g., lower content of phytate, bioavailability of higher ß-carotene, etc.). Such experiments are necessary to demonstrate the nutritive or physiological effect of enhanced valuable ingredients or decreased anti-nutrient substances (Welch and Graham, 2004). These studies should ideally include balance experiments to measure the digestibility/bioavailability; or span either the growing/finishing period for chickens, pigs, and beef cattle; or the major part of the laying period of a laying hen, or lactating cycle for dairy cattle, and should be conducted according to internationally agreed standard protocols (e.g., OECD, 2003b; ILSI, 2003b, 2004; EFSA, 2004) on a scientific basis (Kuiper and Kleter, 2003). Some recommendations from the "Best practices for the conduct of animal studies to evaluate feeds from GMP for input traits" are summarized in Table 3 and should be also used for feeds from GMP with output traits. The genetically modified material to be tested should be included in the diet to a maximum amount consistent with a good diet design and should be compared to diets containing their isogenic counterpart. Apart from the recommendations given in Table 3, slaughtering results should be measured in meat producing animals. Animal health and behaviour and quality of foods of animal origin are further parameters which have to be considered.

\section{EFSA-GUIDANCE document (EFSA, 2004) - GMP of the second generation}

In the EFSA-Guidance document (EFSA, 2004), the following guideline for animal studies with feeds from the second generation of GMP is proposed:

a. In the case of GM crops modified for improved bioavailability of nutrients, livestock studies with the target species should be conducted to determine the bioavailability of individual nutrients in the GM-crop and a range of conventional varieties.

b. In the case of GM-crops specifically modified with traits to enhance animal performance through increased nutrient density (e.g., increased oil content), or an enhanced level of a specific nutrient (e.g., lysine), an appropriate control diet using its nearest genetic counterpart should be formulated by 
supplementing it with the specific nutrient to the extent of the change effected in the GM-crop. It is also suggested that a number of other commercially relevant varieties should be included in the study.

c. In the case of co-products (e.g., oilseeds meals) from which the modified ingredient has been extracted, these can be compared with those derived from an appropriate counterpart and other commercial varieties under the condition that they are essentially free from the modified component.

d. In the case where the nutritional content of animal based foods may be modified following the feeding of animals with nutritionally modified GMfeed, then the content of these nutrients should be assessed in the animal products.

In the case of GM-crops with improved nutritional characteristics, livestock feeding studies with target species should be conducted on a case-by-case basis to study the nutritional benefits that might be expected, and to provide further safety assurance. These studies should span either the time period from the growing and/or finishing period to slaughter for chickens, pigs, and cattle for fattening, or a major part of the laying period of hens, or of a lactation cycle for dairy cows, and should be conducted according to internationally agreed upon standard protocols (ILSI, 2003b). For feedstuffs intended only for aquaculture, growth studies with fish species such as carp or other typical herbivore fishes may be preferable to an extrapolation from results obtained with land-animals.

Studies of this type are, however, limited to those materials suitable for inclusion in the diets and which can be nutritionally matched to a suitable control diet.

\section{ILSI-document to assess nutritionally improved feeds (ILSI, 2004)}

The compositional analyses provide information on the concentration of nutrients, anti-nutritive factors and naturally occurring toxins. The need for analysis of specific compounds should be determined on a case-by-case basis.

Feeding studies on targeted livestock species and categories may be useful to assess the nutritional impact of the intended changes (ILSI, 2004). Depending on the specific nutritional modification being introduced, it may be important to assess nutrient availability in relevant animal studies. The intended changes in each nutritionally improved crop will determine which animal studies are most appropriate. ILSI (2004) recommended the development of guidelines for assessment of nutritionally improved crops. 


\section{STUDIES TO ASSESS INCREASED CONCENTRATION OF DESIRABLE NUTRIENTS}

Presently, no detailed standardized test protocols are available to investigate feeds from the GMP of the second generation. Therefore the following considerations deal with such proposals.

Feeds with intended beneficial physiological properties like amino acids, fatty acids, minerals, vitamins and other substances (see Table 1) may contribute to higher feed intake of animals and/or improved conversion of feed/nutrients into food of animal origin and lower excretion of nitrogen, phosphorus and other nutrients. Depending on the claim of changes as a consequence of the genetic modification, the experimental designs must be arranged to demonstrate the effects. Various experimental designs are necessary to demonstrate the efficiency of changes or of expressed nutrients/constituents:

- Bioavailability or conversion of nutrient precursors into nutrients (e.g., $\beta$-carotene)

- Digestibility/bioavailability of nutrients (e.g., amino acids, fatty acids, vitamins)

- Efficiency of substances which may improve nutrient digestibility/ availability (e.g., enzymes)

- Utilization of substances with surplus effects (e.g., prebiotics)

- Improvement of sensoric properties/palatability of feed (e.g., essential oils, aromas).

Apart from the intended increase of desirable substances, genetic modification could also cause some side effects, as recently discussed by Cellini et al. (2004). Such secondary changes should be considered in the nutritional and safety assessment of GMP of the second generation. Animal studies to serve as the basis of comparative approaches seem to be necessary to answer the questions mentioned. Before experimentation answers must be found for so-called "further questions" mentioned in Figure 2. One of the most important questions for nutritional assessment of GMP of the second generation is the formulation or the type of control or comparison group. No isogenic counterpart could be available in many cases. Therefore a special design must be created to assess the GMP of the second generation. Further general questions such as the: optimal species/categories of animals, number and age of animals, duration of experiment, keeping of animals, and type of measurements should be answered before experimenting according to the general guidelines laid down by the ILSI (2003b; see Table 3) and EFSA (2004) or the recommendations for animal experiments by national or international scientific bodies. Restricted amounts of feeds available from the GMP of the second generation may have important consequences on the experimental design, especially on numbers of groups and animals per group as well as on the duration of experiments. Doseresponse studies with various amounts of feeds from isogenic plants and GMP of the 
second generation in the diets could be very helpful to give adequate answers and could improve the experimental designs given in Tables 4 to 13, but the restricted availability of feed from GMP in an early phase of experimentation may limit those types of nutritional assessment. Level of feed intake may influence the results in some cases. Therefore ad libitum feeding of isogenic and transgenic compounds is recommended to assess the influence on feed intake, but restricted feeding (feeding at adequate levels) seems to be necessary to assess nutritional effects (e.g., digestibility) of the genetic modification.

\section{Conversion of nutrient precursors}

Balance studies with target animal species/categories are necessary to assess the conversion of nutrient precursors (e.g., $\beta$-carotine) into nutrients. At least two groups of animals are necessary to assess the conversion of the precursor into the nutrient (Table 4).

Table 4. Proposal to assess the conversion of nutrient precursors from the second generation of GMP into nutrients (e.g., $\beta$-carotene)

\begin{tabular}{|c|c|c|}
\hline Groups & Diet composition & Measurements \\
\hline $1^{1}$ & $\begin{array}{l}\text { Balanced diets including typical levels of } \\
\text { isogenic counterpart }+\beta \text {-carotene } \\
\text { (level/s adequate to the transgenic crop) }\end{array}$ & $\begin{array}{l}\text { Depends on the claim of genetic } \\
\text { modification: } \\
\text { - concentration of converted } \\
\text { substances in target organ } \\
\text { (e.g., vitamin A in liver })^{2}\end{array}$ \\
\hline $2^{1}$ & $\begin{array}{l}\text { Balanced diets with adequate amounts of } \\
\text { transgenic crop }\end{array}$ & - metabolic parameters \\
\hline
\end{tabular}

${ }^{1}$ equal feed amounts for all animals

${ }^{2}$ until a steady state is achieved in the target organs

Dose-response studies (at least three dosages) with the supplemental precursor and the GMP of the second generation (adequate dosages) could improve the assessment, but are more expensive in terms of time, money and feeding material. Various models to determine the bioavailability of micronutrients have been discussed by House (1999), van Campen and Glahn (1999) and Welch and Graham (2004).

\section{Digestibility of nutrients}

Different types of studies seem necessary to assess the effect/s of the increased content of an essential nutrient in the GMP. Answers should be provided on its digestibility/bioavailability, but also about its effect on feed intake and animal performances (Table 5). 
Table 5. Proposal to assess the effect of essential nutrient/s from the second generation of GMP

\begin{tabular}{lll}
\hline Groups & \multicolumn{1}{c}{ Diet composition } & \multicolumn{1}{c}{ Measurements } \\
\hline 1 & $\begin{array}{l}\text { Balanced diet including typical levels of the } \\
\text { isogenic counterparts plus adequate amounts } \\
\text { of changed substances (e.g., amino acids, } \\
\text { minerals; vitamins etc.) fed } \text { ad libitum }\end{array}$ & $\begin{array}{l}\text { Depends on the claim of genetic } \\
\text { modification: }\end{array}$ \\
& $\begin{array}{l}\text { - precaecal digestibility of amino } \\
\text { acids }\end{array}$ \\
& $\begin{array}{l}\text { Balanced diet including typical levels of the } \\
\text { transgenic crops, feeding amount adequate } \\
\text { to Group 1 }\end{array}$ & $\begin{array}{l}\text { - indicator values for minerals } \\
\text { and vitamins }\end{array}$ \\
& $\begin{array}{l}\text { In the case of lower intake of Group 2 } \\
\text { compared to Group 1; feeding of Group 1 in } \\
\text { adequate feed amounts of Group 2 }\end{array}$ & $\begin{array}{l}\text { - animal performances, feed } \\
\text { efficiency }\end{array}$ \\
& $\begin{array}{l}\text { incorporation in animal tissues } \\
\text { (comparison with control or } \\
\text { In the case of adequate intake of Groups 1 } \\
\text { and 2, ad libitum feeding of Group 2 }\end{array}$ & indicator values) \\
& & - quality of food of animal origin \\
\hline
\end{tabular}

Dose-response studies seem to be helpful in some cases. Studies with restricted (adequate to control) and ad libitum feed intake are recommended if an influence on the of feed intake level is expected.

\section{Effect of enhancer of nutrient utilization}

Expression of substances which improve nutrient utilization is one of the objectives of output traits. Enzymes like phytase or non starch polysaccharides degrading enzymes are examples for such compounds. Efficacy of such substances should be demonstrated using specific experimental designs (Table 6). If any influence on the level of feed intake is expected, the experimental design has to be dramatically extended.

Assessment of substances with surplus effects

Prebiotics may influence processes in the digestive tract (e.g., oligosaccharides, fructans; see Böhme et al., 2005) or the immune response ( $\beta$ glucans). Effects of such substances should be documented in suitable animal experiments (Table 7). 
Table 6. Proposal to assess the effects of enhanced nutrient utilization (e.g., enzymes)

\begin{tabular}{lll}
\hline Groups & \multicolumn{1}{c}{ Diet composition } & \multicolumn{1}{c}{ Measurements } \\
\hline 1 & $\begin{array}{l}\text { Balanced diets including typical } \\
\text { levels of the isogenic counterpart, } \\
\text { ad libitum feeding }\end{array}$ & $\begin{array}{l}\text { Depends on the claim of genetic } \\
\text { modification: }\end{array}$ \\
2 & $\begin{array}{l}\text { Diets of Group 1 plus enhancer } \\
\text { adequate to transgenic crop (or dose- } \\
\text { response studies), feeding level of } \\
\text { Group 1 }\end{array}$ & $\begin{array}{l}\text { - mineralisation (e.g., tibia ash) in } \\
\text { the case of phytase }\end{array}$ \\
& $\begin{array}{l}\text { Balanced diets including typical } \\
\text { levels of the transgenic crop, feeding } \\
\text { level of Groups 1 und 2 }\end{array}$ & - quality of food of animal origin \\
& Diets of Group 2, ad libitum feeding & \\
4 & Diets of Group 3, ad libitum feeding & \\
\hline
\end{tabular}

Table 7. Proposal to assess the effects of substances with surplus effects (e.g., prebiotics)

\begin{tabular}{|c|c|c|}
\hline Groups & Diet composition & Measurements \\
\hline 1 & $\begin{array}{l}\text { Balanced diets including typical } \\
\text { levels of the isogenic counterpart, } \\
\text { ad libitum feeding }\end{array}$ & $\begin{array}{l}\text { Depends on the claim of genetic } \\
\text { modification: } \\
\text { - feed intake }\end{array}$ \\
\hline 2 & $\begin{array}{l}\text { Diets of Group } 1 \text { plus substances } \\
\text { with surplus effects adequate to } \\
\text { transgenic crop (or dose-response } \\
\text { studies), feeding level of Group } 1\end{array}$ & $\begin{array}{l}\text { - digestibility } \\
\text { - microbial change in the digestive } \\
\text { tract }\end{array}$ \\
\hline 3 & $\begin{array}{l}\text { Balanced diets including typical } \\
\text { levels of the transgenic crop, feeding } \\
\text { level of Groups } 1 \text { und } 2\end{array}$ & - animal performances \\
\hline 4 & Diets of Group 2, ad libitum feeding & $\begin{array}{l}\text { - metabolic effects } \\
\text { (immune response, etc.) }\end{array}$ \\
\hline 5 & Diets of Group 3, ad libitum feeding & - quality of food of animal origin \\
\hline
\end{tabular}

Assessment of substances which influence sensoric properties or palatability

Herbs, essential oils and other substances may improve sensoric properties or the palatability of feeds. Some of those properties can be introduced into GMP of the second generation. Their efficiency must be demonstrated in specific experiments including target animal species or categories (Table 8). 
Table 8. Proposal to assess the effects of substances which improve sensoric properties or palatlability (e.g., essential oils)

\begin{tabular}{lll}
\hline Groups & \multicolumn{1}{c}{ Diet composition } & \multicolumn{1}{c}{ Measurements } \\
\hline 1 & $\begin{array}{l}\text { Balanced diets including typical } \\
\text { levels of the isogenic counterpart, } \\
\text { ad libitum feeding }\end{array}$ & $\begin{array}{l}\text { Depends on the claim of } \\
\text { geneticmodification: }\end{array}$ \\
& $\begin{array}{l}\text { Diets of Group 1 plus substance, } \\
\text { adequate to transgenic crop (or } \\
\text { dose-response studies), feeding } \\
\text { level of Group 1 }\end{array}$ & - - digestibility of nutrients \\
3 & $\begin{array}{l}\text { Balanced diets including typical } \\
\text { levels of the transgenic crop, } \\
\text { feeding level of Groups 1 und 2 }\end{array}$ & - animal health \\
4 & $\begin{array}{l}\text { Diets of Group 2, ad libitum } \\
\text { feeding }\end{array}$ & \\
& $\begin{array}{l}\text { Diets of Group 3, ad libitum } \\
\text { feeding }\end{array}$ & \\
\hline
\end{tabular}

\section{STUDIES TO ASSESS THE DECREASED CONCENTRATION OF UNDE- SIRABLE SUBSTANCES}

Undesirable substances like phytate, alkaloids, glucosinolates, mycotoxins, etc. (see ILSI, 2004) may affect feed intake, animal health and performance negatively, but also nutrient availability and metabolic parameters. Reduction of undesirable substances in crops is one of the most important objectives of genetic modification. It seems to be more important than the increase of desirable nutrients. Desirable substances can mostly be added to the diets via feed additives. Removing undesirable substances is expensive and sometimes impossible. Therefore many output traits are intended to benefit animals and consumers by lower concentrations of undesirable substances. In accordance with desirable nutrients, such claims must be demonstrated in adequate experiments. Studies on the target animal species/ categories should be preferred from the view of animal nutrition.

\section{Lower concentration of inhibiting substances}

Some years ago, Spencer et al. (2000) demonstrated, in an excellently designed experiment, the effect of low-phytate maize on the phosphorus utilization in pigs (Table 9). High portions of control maize (78.5\%) were replaced by low-phytate maize, both diets were fed either unsupplemented or supplemented with inorganic phosphorus. Results demonstrate impressively that the available phosphorus from low-phytate 
maize is adequate to the inorganic P supplementation (2.0 or $1.5 \mathrm{~g} \mathrm{P} / \mathrm{kg}$ feed; Table 9). Digestion experiments may complete those feeding studies (Table 10).

Table 9. Conventional and low-phytate maize ( $78.5 \%$ of the mixture) in the feed of fattening pigs (from Spencer et al., 2000)

\begin{tabular}{|c|c|c|c|c|c|}
\hline \multirow{2}{*}{\multicolumn{2}{|c|}{$\begin{array}{l}\text { Indices } \\
\text { Inorganic P supplement }\end{array}$}} & \multicolumn{2}{|c|}{$\begin{array}{l}\text { Control } \\
(0.3 \text { g of available } \\
\text { P per } \mathrm{kg})\end{array}$} & \multicolumn{2}{|c|}{$\begin{array}{l}\text { Low-phytate maize } \\
(1.7 \mathrm{~g} \text { of available } \\
\text { P per } \mathrm{g})\end{array}$} \\
\hline & & - & + & - & + \\
\hline \multicolumn{6}{|c|}{$\mathrm{P}$ content, $\mathrm{g} / \mathrm{kg}$} \\
\hline \multicolumn{2}{|c|}{29 - $73 \mathrm{~kg}$ liveweight } & 3.4 & $5.4^{1}$ & 3.4 & $5.4^{1}$ \\
\hline \multicolumn{2}{|c|}{73 - $112 \mathrm{~kg}$ liveweight } & 3.2 & $4.7^{2}$ & 3.2 & $4.7^{2}$ \\
\hline \multicolumn{2}{|c|}{ Feed intake, $\mathrm{kg} / \mathrm{d}$} & $2.23^{\mathrm{a}}$ & $2.50^{\mathrm{b}}$ & $2.53^{\mathrm{b}}$ & $2.51^{\mathrm{b}}$ \\
\hline \multicolumn{2}{|c|}{ Liveweight gain, $\mathrm{g} / \mathrm{d}$} & $730^{\mathrm{a}}$ & $870^{\mathrm{b}}$ & $900^{\mathrm{b}}$ & $880^{\mathrm{b}}$ \\
\hline \multicolumn{2}{|c|}{ Feed consumption, $\mathrm{kg} / \mathrm{kg}$} & $3.05^{\mathrm{a}}$ & $2.87^{\mathrm{b}}$ & $2.81^{\mathrm{b}}$ & $2.85^{\mathrm{b}}$ \\
\hline \multicolumn{2}{|c|}{$\mathrm{P}$ excreted, $\mathrm{g} / \mathrm{kg}$} & $4.6^{\mathrm{a}}$ & $8.9^{\mathrm{c}}$ & $3.8^{\mathrm{b}}$ & $8.8^{\mathrm{c}}$ \\
\hline \multicolumn{2}{|c|}{ Strength, 4th metacarpal bone, $\mathrm{kg}$} & $79.4^{\mathrm{a}}$ & $138.5^{\mathrm{bc}}$ & $132.2^{\mathrm{b}}$ & $153.9^{\mathrm{d}}$ \\
\hline \multicolumn{2}{|c|}{ Ash content, $\%$ in 4 th metacarpal bone } & $53.5^{\mathrm{a}}$ & $60.1^{\mathrm{bc}}$ & $59.3^{\mathrm{b}}$ & $61.2^{\mathrm{c}}$ \\
\hline \multicolumn{6}{|c|}{$\begin{array}{l}\text { a,b,c,d different letters in one line indicate significant differences }(\mathrm{P}<0.05) \\
{ }^{1}+2.0 \mathrm{~g} \mathrm{P} / \mathrm{kg}^{2}+1.5 \mathrm{~g} \mathrm{P} / \mathrm{kg}\end{array}$} \\
\hline \multicolumn{6}{|c|}{ Table 10. Proposal to assess the effects of inhibitors of nutrient bioavailability (e.g., phytate) } \\
\hline Groups & \multicolumn{2}{|c|}{ Diet composition } & \multicolumn{3}{|c|}{ Measurements } \\
\hline 1 & \multicolumn{2}{|c|}{$\begin{array}{l}\text { Balanced diet including typical levels } \\
\text { of isogenic counterpart, ad libitum } \\
\text { feeding }\end{array}$} & \multicolumn{3}{|c|}{$\begin{array}{l}\text { Depends on the claim of genetic } \\
\text { modification: }\end{array}$} \\
\hline 2 & \multicolumn{2}{|c|}{$\begin{array}{l}\text { Diets of Group } 1 \text { plus inhibited } \\
\text { nutrient (e.g., P), ad libitum feeding }\end{array}$} & $\begin{array}{l}\text { - grow } \\
\text { anim }\end{array}$ & periment & target \\
\hline 3 & \multicolumn{2}{|c|}{$\begin{array}{l}\text { Balanced diet including transgenic } \\
\text { counterpart in adequate levels to } \\
\text { Group } 1 \text { (e.g., low phytate crop) }\end{array}$} & $\begin{array}{r}- \text { conce } \\
\text { in ind }\end{array}$ & $\begin{array}{l}\text { n of inhil } \\
\text { organs }\end{array}$ & d nutrient \\
\hline 4 & \multicolumn{2}{|c|}{$\begin{array}{l}\text { Diets of Group } 3 \text { plus inhibited } \\
\text { nutrient of Group } 2\end{array}$} & & & \\
\hline
\end{tabular}

\section{Lower concentration of toxic substances}

Genetic modification may directly or indirectly contribute to lower concentrations of toxic substances. A direct decrease means a reduction by genetic modification such as a lower concentration of glucosinolates, allergenic substances, etc. An indirect decrease could be a secondary effect of genetic modification as a lower contamination of Bt-maize with Fusarium toxins in 
consequence of reduced infection with the European maize borer. Animal studies to demonstrate the effects of lower concentrations of toxic substances in GMP in comparison with isogenic counterparts seem to be necessary (Table 11).

Table 11. Proposal to assess the effects of lower concentration of toxic substances (e.g., lower mycotoxin levels)

\begin{tabular}{lll}
\hline Groups & \multicolumn{1}{c}{ Diet composition } & \multicolumn{1}{c}{ Measurements } \\
\hline 1 & $\begin{array}{l}\text { Balanced diet including typical levels } \\
\text { of isogenic counterpart, ad libitum } \\
\text { feeding }\end{array}$ & $\begin{array}{l}\text { Depends on claim of genetic } \\
\text { modification: }\end{array}$ \\
2 & $\begin{array}{l}\text { Balanced diet including transgenic } \\
\text { counterpart in adequate levels to } \\
\text { Group 1, ad libitum feeding }\end{array}$ & $\begin{array}{l}\text { - feed intake } \\
\text { efficacy }\end{array}$ \\
3 & $\begin{array}{l}\text { Group 2, feeding level adequate to } \\
\text { Group 1 }\end{array}$ & $\begin{array}{l}\text { - toxin concentration in indicator } \\
\text { samples and in food of animal } \\
\text { origin }\end{array}$ \\
& & - quality of food of animal origin \\
\hline
\end{tabular}

\section{Lower concentration of cell wall constituents}

Some kinds of cell wall constituents such as lignin and silicate could be reduced by traditional plant breeding. $\mathrm{Bm}_{3}$-maize and sorghum hybrids are lower in lignin and therefore higher in digestibility. Animal studies should be carried out with ruminants (Table 12).

Table 12. Proposal to assess the effects of lower cell wall constituents (e.g., lower lignin)

\begin{tabular}{lll}
\hline Groups & \multicolumn{1}{c}{ Diet composition } & \multicolumn{1}{c}{ Measurements } \\
\hline 1 & $\begin{array}{l}\text { Balanced diet including typical levels } \\
\text { of isogenic counterpart, } \\
\text { ad libitum feeding }\end{array}$ & $\begin{array}{l}\text { Depends on claim of genetic } \\
\text { modification: }\end{array}$ \\
2 & $\begin{array}{l}\text { Balanced diet including transgenic } \\
\text { counterpart in adequate levels to } \\
\text { Group 1, ad libitum feeding }\end{array}$ & - in sacco cell wall degradability \\
3 & $\begin{array}{l}\text { Group 2, feeding level adequate to } \\
\text { Group 1 }\end{array}$ & - feed intake \\
& & \\
\end{tabular}




\section{STUDIES TO ASSESS GMPs WITH MORE THAN ONE SUBSTANTIAL CHANGE}

In the future, GMP of the second generation with more than one modified output trait could be available. Experimental designs have to consider these claims and results must demonstrate the intended changes. Of course more experimental groups seem to be necessary in such cases as demonstrated in Tables 4 to 12 .

Case by case studies should be carried out to show the bioavailability/effect of each changed nutrient or of each decreased content of undesirable substances. If isogenic controls are not available, traditional hybrids should act as comparators supplemented with adequate nutrients (Table 13).

Table 13. Proposal for the nutritive assessment of feeds from GMPs of the second generation with more than one output trait

\begin{tabular}{lll}
\hline Groups & \multicolumn{1}{c}{ Diet composition } & \multicolumn{1}{c}{ Measurements } \\
\hline 1 & $\begin{array}{l}\text { Balanced diet including typical } \\
\text { levels of isogenic or near isogenic } \\
\text { counterpart, ad libitum feeding }\end{array}$ & $\begin{array}{l}\text { Depends on the claims of genetic } \\
\text { modification: }\end{array}$ \\
2 & $\begin{array}{l}\text { Diet of Group 1 plus nutrients A, } \\
\text { B...(adequate amounts of Diet 3), } \\
\text { feeding adequate to Group 1 }\end{array}$ & - analysis and in vitro measurements \\
& $\begin{array}{l}\text { Balanced diet including typical } \\
\text { levels of transgenic crop, feeding } \\
\text { adequate to Group 1 }\end{array}$ & - feed intake \\
& Diets of Group 2, ad libitum feeding & - animal performances, feed efficacy \\
4 & Diets of Group 3, ad libitum feeding \\
5 & & - incorporation in animal tissues \\
& & - quality of food of animal origin \\
\hline
\end{tabular}

\section{FURTHER DEVELOPMENTS}

Further studies, or measurements in studies mentioned before, depend on the type of genetic modification. Case-by-case decisions are necessary to investigate the influence of genetic modification on animal health and reproduction/fertility of the animal. Long term studies (more generations) could be necessary in some cases. Animal models for such studies could be quails for poultry, rats or mice for pigs, and goats for ruminants. More details for further studies with feed/food from GMP of the second generation are mentioned by OECD (2003b), EFSA (2004) and ILSI (2004).

Transgenic animals (Sang, 2003) and fish (Maclean, 2003) could be available in the future. For example, Golovan et al. (2001) described the "phytase transgenic 
pig." The saliva of these pigs contains the enzyme phytase, which allows the pigs to digest phytase-phosphorus. Other enzyme excretions or metabolic processes could be also manipulated by genetic modification. But there is still a lot of research required to identify useful targets for genetic modification and to increase overall efficiency of the expensive genetic modification methods in food producing animals (Sang, 2003). Special studies are necessary to assess the manipulation of animals.

\section{CONCLUSIONS}

In the future, more feed from GMP will be available for animal nutrition as whole crops, crop components or co-products.

Many animal studies with target species/categories were carried out for nutritional assessment of GM-feeds modified in terms of agronomic input traits (GMP of the first generation). Compositional equivalence has been established in such feeds, feeding studies generally contribute only little to the nutritional assessment.

Feeds from GMP of the second generation (with output traits) are characterized by intended beneficial nutritive properties, such as increased contents of valuable nutrients or decreased concentrations of anti-nutritive substances. Specific animal feeding studies should be conducted with the target species to confirm the expected nutritional properties of the modified crops, their components or coproducts depending on the type of modification.

Proposals for adequate studies for nutritional assessments of such feeds have been submitted and further discussions seem to be necessary.

\section{REFERENCES}

Aumaitre A., Aulrich K., Chesson A., Flachowsky G., Piva G., 2002. New feeds from genetically modified plants: Substantial equivalence, nutritional equivalence, digestibility, and safety for animals and the food chain. Livest. Prod. Sci. 74, 223-238

Böhme H., Hommel B., Flachowsky G., 2005. Nutritional assessment of silage from transgenic inulin synthesising potatoes for pigs. J. Anim. Feed Sci.. 14, Suppl. 1, ...-...

Cellini F., Chesson A., Coquhonn I., Constable A., Davies H.V., Engel K.-H., Gatehouse A.M.R., Kärenlampi S., Kok E.J., Legnay J.J., Lehesranta S., Noteborn H.P.J.M., Pedersen J., Smith M., 2004. Unintended effects and their detection in genetically modified crops. Food Chem. Toxicol. 42, 1089-1123

Chesson A., Flachowsky G., 2003. Transgenic plants in poultry nutrition. World Poultry Sci. J. 59, 201-207

Clark J.H., Ipharraguerre I.R., 2001. Livestock performance: Feeding biotech crops. J. Dairy Sci. 84, E. Suppl., E9-E18, 237-249 
EC, 1997. Verordnung (EG) Nr. 258/97 des Europäischen Parlaments und des Rates vom 21.01.1997 über neuartige Lebensmittel und neuartige Lebensmittelzutaten. Amtsblatt der Europäischen Gemeinschaft Nr. L 43/1

EFSA, 2004. Guidance document of the scientific panel on genetically modified organisms for the risk assessment of genetically modified plants and derived food and feed. EFSA J. 99, 1-93

Faust M.A., 2002. New feeds from genetically modified plants: the US approach to safety for animals and food chain. Livest. Prod. Sci. 74, 239-254

Flachowsky G., Aulrich K., 2001a. Zum Einsatz gentechnisch veränderter Organismen (GVO) in der Tierernährung. Übers. Tierernähr. 29, 45-79

Flachowsky G., Aulrich K., 2001b. Nutritional assessment of GMO in animal nutrition. J. Anim. Feed Sci. 10, Suppl. 1, 181-194

Flachowsky G., Chesson A., Aulrich K., 2005. Animal nutrition with feeds from genetically modified plants. Arch. Anim. Nutr. 59, 1-40

Golovan S.P., Meidinger R.G., Ajakaiye A., Cottrill M., Wiederkehr M.Z., Barney D.J., Plante C., Pollard. J.W., Fan M.Z., Hayes M.A., Laursen J., Hjorth J.P., Hacker R.R., Phillips J.P., Forsberg C.W., 2001. Pigs expressing salivary phytase produce low-phosphorus manure. Biotechnology $19,741-745$

House W.A., 1999. Trace element bioavailability as exemplified by iron and zinc. Field Crops Res. 60, 115-141

ILSI, 2003a. Crop Composition Database. $<$ http://www.cropcomposition.org >. Accessed 2003 July 14

ILSI, 2003b. Best practices for the conduct of animal studies to evaluate crops genetically modified for input traits. International Life Sciences Institute, Washington, DC, p. 62 http//www.ilsi.org/ file/bestpracticescas.pdf

ILSI, 2004. Nutritional and safety assessments of foods and feeds nutritionally improved through biotechnology. Compr. Rev. Food Sci. Food Saf. 3, 36-104

James C., 2004. Global status of commercialised transgenic crops: 2004. ISAA: Ithaca, NY. http: //www.isaaa.org

Kuiper H.A., Kleter G.A., 2003. The scientific basis for risk assessment and regulation of genetically modified foods. Trends Food Sci. Technol. 14, 277-293

Lheureux K., Menrad K., 2004. A decade of European field trials with genetically modified plants. Environ. Biosafety Res. 3, 99-107

Maclean N., 2003. Genetically modified fish and their effects on foods quality and human health and nutrition. Trend Food Sci. Technol. 14, 242-252

OECD, 1993. Safety evaluation of foods derived by modern biotechnology: concepts and principles. Paris (France)

OECD, 2001a. Series on the Safety of Novel Foods and Feeds No. 1. Consensus document on key nutrients and key toxicants in low erucic acid rapeseed (canola). Organisation for Economic Cooperation and Development. Paris (France)

OECD, 2001b. Series on the Safety of Novel Foods and Feeds No. 2: Consensus document on compositional considerations for new varieties of soybean: key food and feed nutrients and antinutrients. Organisation for Economic Co-operation and Development. Paris (France)

OECD, 2002a. Series on the Safety of Novel Foods and Feeds No. 3: Consensus document on compositional considerations for new varieties of sugar beet: key food and feed nutrients and anti-nutrients. Organisation for Economic Co-operation and Development. Paris (France)

OECD, 2002b. Series on the Safety of Novel Foods and Feeds No. 4: Consensus document on compositional considerations for new varieties of potatoes: key food and feed nutrients, antinutrients and toxicants. Organization for Economic Co-operation and Development. Paris (France) 
OECD, 2002c. Series on the Safety of Novel Foods and Feeds No. 6: Consensus document on compositional for new varieties of maize (Zea mays): key food and feed nutrients and anti-nutrients and secondary metabolites. Organization for Economic Co-operation and Development. Paris (France)

OECD, 2002d. Report of the OECD workshop on nutritional assessment of novel foods and feeds. 57 February 2001. Ottawa, Canada. Organization for Economic Co-operation and Development. Paris (France)

OECD, 2003a. Series on the Safety of Novel Foods and Feeds No. 7: Consensus document on compositional considerations for new varieties of bread wheat (Triticum aestivum): key food and feed nutrients, anti-nutrients and toxicants. Organization for Economic Co-operation and Development. Paris (France)

OECD, 2003b. Series on the Safety of Novel Foods and Feeds No. 9: Considerations for the safety assessment of animal feedstuffs derived from genetically modified plants. Organization for Economic Co-operation and Development. Paris (France)

Sang H., 2003. Genetically modified livestock and poultry and their potential effects on human health and nutrition. Trends Food Technol. 14, 253-263

Spencer J.D., Allee G.L., Sauber T.E., 2000. Growing-finishing performance and carcass characteristics of pigs fed normal and genetically modified low-phytate corn. J. Anim. Sci. 78, $1529-1536$

Van Campen D.R., Glahn R.P., 1999. Micronutrient bioavailability techniques: accuracy, problems and limitations. Field Crops Res. 60, 93-113

Welch R.M., Graham R.D., 2004. Breeding for micro-nutrients in staple food crops from a human nutrient perspective. J. Exp. Botany 55, 353-364

\section{STRESZCZENIE}

\section{Propozycje oceny żywieniowej pasz pochodzących z genetycznie modyfikowanych roślin}

Uprawa genetycznie modyfikowanych roślin (GMP) zwiększyła się z 1,7 do $81 \mathrm{mln}$ ha w latach od 1996 do 2004 (James, 2004). Naukowcy i farmerzy, a także konsumenci potrzebują ich oceny żywieniowej, łącznie $\mathrm{z}$ aspektami bezpieczeństwa pasz pochodzących z takich roślin.

Przy ocenie przyjęto za podstawę równoważność wartości pasz niemodyfikowanych z GMP pierwszej generacji (bez istotnej zmiany w składzie lub cechach produkcyjnych), która to podstawa jest szeroko akceptowana. Niezbędne jednakże są wszechstronne badania pasz pochodzących z GMP drugiej generacji, z istotnymi zmianami w składzie i wartości żywieniowej lub cechach produkcyjnych.

Praca podsumowuje propozycje oceny żywieniowej pasz z GMP pierwszej generacji i dyskutuje modele doświadczalne dla oceny pasz z GMP drugiej generacji. 